einstein

Official Publication of the Instituto Israelita

de Ensino e Pesquisa Albert Einstein

ISSN: 1679-4508 | e-ISSN: 2317-6385
How to cite this article:

Batista JM, Martins MA, Bertollo CM. Primary

cutaneous histoplasmosis difficult to treat in immunocompetent patient: case report and literature review. einstein (São Paulo). 2021;19:eRC5488.

Corresponding author:

Caryne Margotto Bertollo

Avenida Presidente Antônio Carlos, 6.627

room 3026, building B2 - Pampulha

Zip code: 31270-901 - Belo Horizonte, MG, Brazil

Phone: (55 31) 3409-6941

E-mail: carynemb@gmail.com

Received on:

Dec 18, 2019

Accepted on:

Jan 12, 2021

Copyright 2021

(c) BY

This content is licensed

under a Creative Commons

Attribution 4.0 International License.
CASE REPORT

\section{Primary cutaneous histoplasmosis} difficult to treat in immunocompetent patient: case report and literature review

\author{
Histoplasmose cutânea primária de difícil tratamento em \\ paciente imunocompetente: relato de caso \\ e revisão da literatura \\ Jéssica Mauricio Batista', Maria Auxiliadora Parreiras Martins', Caryne Margotto Bertollo¹
'Faculdade de Farmácia, Universidade Federal de Minas Gerais, Belo Horizonte, MG, Brazil.
}

DOI: 10.31744/einstein_journal/2021RC5488

\section{ABSTRACT}

Histoplasmosis is an infection caused by the dimorphic fungus Histoplasma capsulatum. The disease is endemic in several regions of tropical and temperate climate. The fungus presents opportunistic behavior, causing widespread infection in immunocompromised patients, resulting from complication of primary pulmonary infection, due to exogenous reinfection or reactivation of a quiescent source. In immunocompetent individuals, approximately $95 \%$ of pulmonary infections are asymptomatic. However, prolonged exposure to high amount spores may lead to acute or chronic lung infection. Due to the low amount of inoculum, primary cutaneous histoplasmosis caused by traumatic implantation is extremely rare and effectively treated with triazoles. Thus, the present study aims to report a case of primary cutaneous histoplasmosis that is difficult to treat in an immunocompetent patient, and to review the literature on the incidence of drug-resistant Histoplasma capsulatum strains in clinical practice.

Keywords: Histoplasmosis; Histoplasma; Immunocompetence; Itraconazole

\section{RESUMO}

A histoplasmose é uma infecção causada pelo fungo dimórfico Histoplasma capsulatum. A doença é endêmica em diversas regiões de clima tropical e temperado. 0 fungo apresenta comportamento oportunístico, causando infecção disseminada em pacientes imunocomprometidos, resultante da complicação da infecção pulmonar primária, por reinfecção exógena ou reativação de um foco quiescente. Em indivíduos imunocompetentes, cerca de $95 \%$ das infecções pulmonares são assintomáticas. No entanto, a exposição prolongada à quantidade elevada de esporos pode levar à infecção pulmonar aguda ou crônica. Devido à baixa quantidade de inóculo, a histoplasmose cutânea primária causada por implantação traumática é extremamente rara e efetivamente tratada com triazóis. Assim, o presente estudo tem como objetivos relatar um caso de histoplasmose cutânea primária de difícil tratamento em paciente imunocompetente, e revisar a literatura a respeito da incidência de cepas de Histoplasma capsulatum resistentes aos fármacos utilizados na prática clínica.

Descritores: Histoplasmose; Histoplasma; Imunocompetência; Itraconazol

\section{INTRODUCTION}

The etiologic agent of histoplasmosis, Histoplasma capsulatum, is a dimorphic fungus found in the form of filamentous mycelium, with micro and macroconidia, 
in soil contaminated by bird and bat feces. ${ }^{(1)}$ The disease is endemic in tropical and temperate climate regions, such as in the river valleys of North and Central America, South America, eastern and southern Europe, eastern Asia, Africa, and Australia. In Brazil, the disease is present in all regions. The state of Rio de Janeiro, however, accounts for the largest number of microepidemics. Outbreaks of histoplasmosis have been associated with activities that disturb contaminated soil, favoring the inhalation of spores. ${ }^{(2,3)}$

In immunocompromised patients, histoplasmosis often presents as disseminated disease resulting from a complication of a primary pulmonary infection, due to exogenous reinfection or reactivation of a quiescent source. In these patients, skin lesions occur in $4 \%$ to $11 \%$ of cases and result from secondary invasion of the skin due to hematogenic dissemination of infected macrophages. ${ }^{(1)}$ The mortality associated with untreated disseminated histoplasmosis is $80 \%$. However, it can be reduced to $2 \%$ with appropriate therapy. For moderately severe to severe cases, liposomal amphotericin B $(3 \mathrm{mg} / \mathrm{kg} /$ day $)$ is recommended for 1 to 2 weeks, followed by itraconazole (200mg orally) three times daily, for 3 days, and then twice daily, for at least 12 months (level of evidence AI). For mild to moderate cases, the use of amphotericin B is not necessary (level of evidence AII). ${ }^{(3)}$

In contrast, in immunocompetent individuals, approximately $95 \%$ of pulmonary infections are asymptomatic. ${ }^{(1)}$ Nevertheless, prolonged exposure to a high amount of spores can lead to an acute but self-limited pulmonary infection. In individuals over 50 years, who smoke, diagnosed with chronic obstructive pulmonary disease (COPD), the lung infection can slowly progress to the chronic fibrocavitary form. ${ }^{(2)}$ In such cases, the use of itraconazole with the same dosage as mentioned above is indispensable, achieving an effective response in $80 \%$ of cases (level of evidence AII). However, the duration of treatment can increase from 12 to 24 months because of the risk of relapse. ${ }^{(3)}$

Due to the low amount of inoculum, the occurrence of primary cutaneous histoplasmosis $(\mathrm{PCH})$ by traumatic implantation, is extremely rare in nonimmunocompromised patients and is effectively treated with triazoles. ${ }^{(1)}$ Thus, the aim of the present study is to report a case of difficult-to-treat $\mathrm{PCH}$ case in an immunocompetent patient with no history of previous exposure to risky environments, such as caves and poultry facilities, and to review the literature on the incidence of $H$. capsulatum strains resistant to drugs used in clinical practice.

\section{CASE REPORT}

A 26-year-old female patient, brown-skin, born, and living in Belo Horizonte (MG), presented with an erythematous papular lesion with irregular borders and centrifugal growth, on the dorsal region of the nose, measuring approximately $1 \mathrm{~cm}$ in diameter (Figure 1). The skin lesion developed after the removal of a comedone, without the use of aseptic techniques, 4 months before clinical treatment. There was no history of systemic symptoms, significant past diseases, or use of relevant medicines. Serological tests (antihepatitis C, anti-hepatitis B, VDRL, and anti-HIV) were negative. Blood tests (complete blood count, lipid profile, prothrombin time and activity, activated partial thromboplastin time, and fasting glucose) showed no abnormalities.

The macroscopic analysis of the incisional biopsy of the lesion showed a skin fragment measuring $0.6 \times 0.4 \times 0.3 \mathrm{~cm}$, with an irregular epidermal surface. Histopathological examination revealed a chronic, diffuse inflammatory process, with dense lymphoplasma-histiocytic infiltrate (Figure 2). A periodic acid Schiff stain (PAS) and a Grocott-Gomori's methenamine silver stain showed numerous spore-like fungal structures stained in red and dark brown, respectively. The fungi showed remarkably regular morphology, presenting as small, well-defined, slightly oval yeasts, approximately $2 \mathrm{~mm}$ to $4 \mathrm{~mm}$ in size, forming rows.

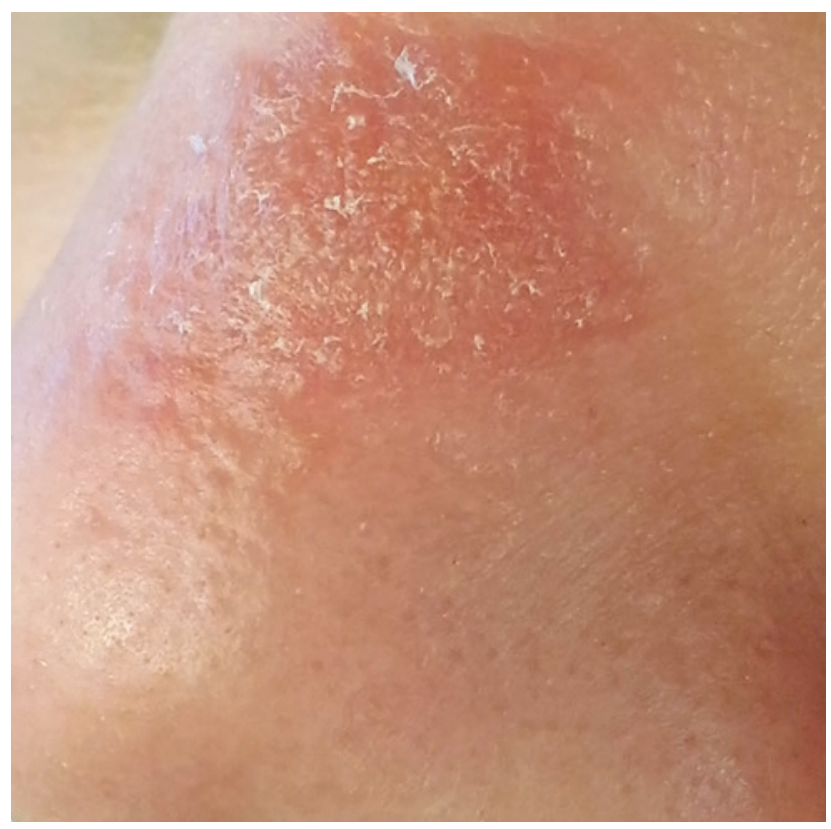

Figure 1. Erythematous papular lesion 


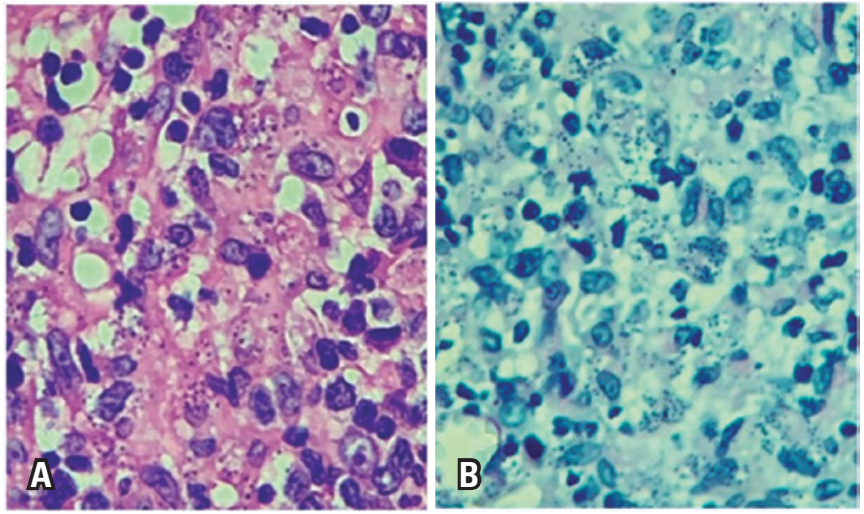

Figure 2. Histoplasma capsulatum yeast form stained by periodic acid Schiff (A) and Grocott-Gomori methenamine silver (B)

Conventional chest radiography revealed clear lungs with no signs of pleuropulmonary injury, wellconfigured hila, free costophrenic angles, normal cardiothoracic index, and unaltered bone structure (Figure 3). No characteristic lesions of acute pulmonary histoplasmosis were found, such as presence of reticulonodular infiltrates accompanied by hilar and paratracheal lymphadenopathy.

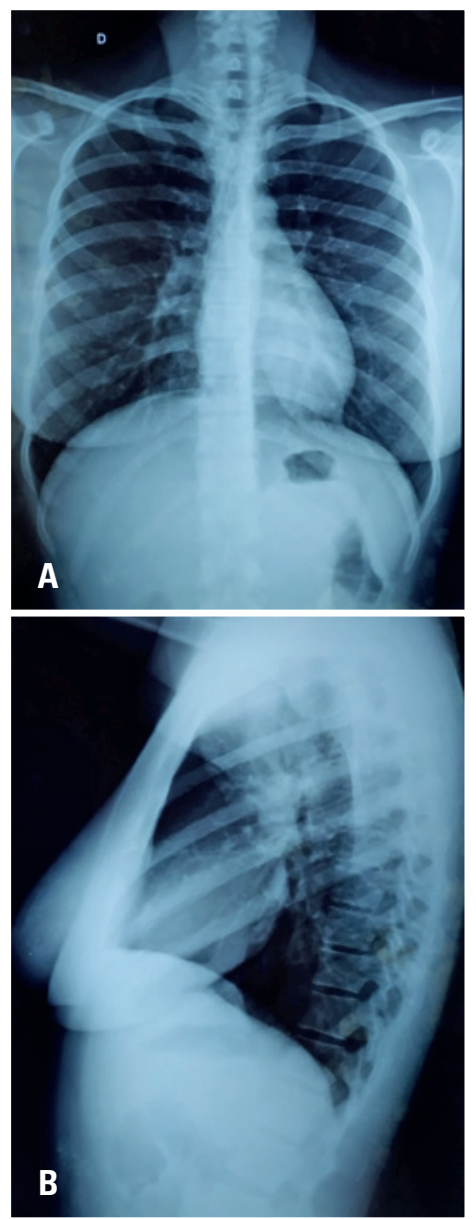

Figure 3. Plain chest radiography in posteroanterior $(A)$ and lateral $(B)$ views
The diagnosis of $\mathrm{PCH}$ was based on the history of traumatic inoculation with subsequent development of a local lesion, identification of the etiologic agent by histopathological examination, and absence of clinical and laboratory evidence of prior systemic or pulmonary infection. Treatment with oral itraconazole, $400 \mathrm{mg}$ a day, was initiated. Complete remission of the lesion occurred after 14 months of uninterrupted treatment. There were no significant changes in the serum indicators of liver damage during treatment - aspartate aminotransferase (AST), alanine aminotransferase (ALT), gamma glutamyl transferase (GGT), and alkaline phosphatase enzymes.

The study was approved by the Research Ethics Committee of Universidade Federal de Minas Gerais (CAAE: 37956820.2.0000.5149, parecer 4.383.903) and the Informed Consent Terms were signed by those responsible.

\section{DISCUSSION}

The clinical manifestations of $\mathrm{PCH}$ can be similar to other infectious diseases. Therefore, the diagnosis depends mainly on the identification of the etiologic agent in histopathological examinations and/or culture, in addition to clinical and laboratory proof of the absence of prior pulmonary or systemic infection. ${ }^{(1)}$ It is worth mentioning that some authors have proposed the use of the Wilson criteria to distinguish $\mathrm{PCH}$ from secondary cutaneous histoplasmosis. ${ }^{(4,5)}$ However, over time, some caveats have been raised: the histoplasmin skin test does not distinguish between current and previous infections; not all lesions present with a chancre form appearance and are accompanied by lymphadenopathy; and, in immunocompromised patients, serum titers decrease or disappear with disease progression. ${ }^{(1)}$

Indeed, in individuals with an intact immune system, $\mathrm{PCH}$ is a rare clinical condition, mainly due to nonprogression of infection. ${ }^{(6)}$ Saheki et al. ${ }^{(1)}$ performed an extensive literature review, finding only eight cases since the first, described by Curtis and Cawley, in 1947. Between 2008 and 2018, five new cases of the disease were reported, ${ }^{(1,6-9)}$ and none was associated with immunosuppression. Of the 13 cases reported in the literature, six showed spontaneous remission, ${ }^{(1)}$ two were mistreated with antibiotics, ${ }^{(1)}$ two were treated with liposomal amphotericin $\mathrm{B},{ }^{(7,9)}$ and three with itraconazole..$^{(1,6,9)}$

Among the cases treated with antifungal drugs (Table 1), complete remission of the lesions occurred within a maximum of 8 weeks of treatment. The ability to eradicate infections in immunocompetent patients, 
Table 1. Studies reporting cases of primary cutaneous histoplasmosis in immunocompetent patients treated with liposomal amphotericin B and/or triazoles

\begin{tabular}{|c|c|c|c|c|c|c|c|}
\hline Study & Type & Sex & $\begin{array}{c}\text { Age } \\
\text { (years) }\end{array}$ & Treatment & Lesion & $\begin{array}{l}\text { Remission } \\
\text { (weeks) }\end{array}$ & Comments \\
\hline Saheki et al.(1) & $\begin{array}{l}\text { Case report } \\
\text { and review }\end{array}$ & Male & 45 & Itraconazole & Single & 6 & $\begin{array}{l}\text { Patient with erythematous papular-tuberous lesion on the } \\
\text { dorsum of the right hand. Treatment with itraconazole } \\
\qquad(400 \mathrm{mg} / \text { day, PO) }\end{array}$ \\
\hline Paixão et al. ${ }^{(6)}$ & Case report & Male & 70 & Itraconazole & Multiple & 4 & $\begin{array}{l}\text { Patient with erythematous genital lesions. } \\
\text { Treatment with itraconazole ( } 200 \mathrm{mg} / \text { day, PO) }\end{array}$ \\
\hline Raina et al. ${ }^{(7)}$ & Case report & Male & 32 & $\begin{array}{c}\text { Liposomal } \\
\text { amphotericin B }\end{array}$ & Single & 3 & $\begin{array}{l}\text { Patient with ulcerated lesion on the right thigh. } \\
\text { Treatment with liposomal amphotericin B (3mg/kg/day) }\end{array}$ \\
\hline Bhattacharya et al. ${ }^{(8)}$ & Case report & Male & 70 & Fluconazole & Multiple & NR & $\begin{array}{l}\text { Patient with nodular lesions on the face, head, neck, } \\
\text { and trunk. Posology not reported. }\end{array}$ \\
\hline Patra et al. ${ }^{|9\rangle}$ & Case report & Male & 60 & $\begin{array}{l}\text { Liposomal } \\
\text { amphotericin B } \\
\text { and itraconazole }\end{array}$ & Multiple & 8 & $\begin{array}{l}\text { Patient with erythematous papular lesions on the } \\
\text { trunk, face, and upper limbs. Treatment with liposomal } \\
\text { amphotericin B ( } 3 \mathrm{mg} / \mathrm{kg} / \mathrm{day} \text { ) for } 8 \text { days, followed by } \\
\text { itraconazole ( } 400 \mathrm{mg} / \text { day, PO) }\end{array}$ \\
\hline
\end{tabular}

the progression of the lesion, and the unusual need for prolonged treatment (14 months of uninterrupted treatment with itraconazole) make the present case report noteworthy.

\section{AUTHORS' INFORMATION}

Batista JM: http://orcid.org/0000-0003-1031-8736

Martins MA: http://orcid.org/0000-0002-5211-411X

Bertollo CM: http://orcid.org/0000-0002-4115-559X

\section{REFERENCES}

1. Saheki MN, Schubach AO, Salgueiro MM, Conceição-Silva F, Wanke B, Lazera M. Histoplasmose cutânea primária: relato de caso em paciente imunocompetente e revisão de literatura. Rev Soc Bras Med Trop. 2008;41(6):680-2.

2. Ferreira MS, Borges AS. Histoplasmosis. Rev Soc Bras Med Trop. 2009; 42(2):192-8. Review.
3. Wheat LJ, Freifeld AG, Kleiman MB, Baddley JW, McKinsey DS, Loyd JE, Kauffman CA; Infectious Diseases Society of America. Clinical practice guidelines for the management of patients with histoplasmosis: 2007 update by the Infectious Diseases Society of America. Clin Infect Dis. 2007;45(7):807-25.

4. Tesh RB, Schneidau JD Jr. Primary cutaneous histoplasmosis. N Engl J Med. 1966;275(1):597-9.

5. Tosh FE, Balhuizen J, Yates JL, Brasher CA. Primary cutaneous histoplasmosis: report of a case. Arch Intern Med. 1964;114:118-9.

6. Paixão M, Miot HA, Avancini J, Belda Júnior W. Primary cutaneous histoplasmosis developed in the penis of an immunocompetent patient. An Bras Dermatol. 2015;90(2):255-7.

7. Raina RK, Mahajan V, Sood A, Saurabh S. Primary cutaneous histoplasmosis in an immunocompetent host from a nonendemic area. Indian J Dermatol. 2016;61(4):467.

8. Bhattacharya JB, Rani P, Aggarwal R, Kaushal S. Primary cutaneous histoplasmosis masquerading as lepromatous leprosy. J Clin Diagn Res. 2017;11(1):ED01-ED02.

9. Patra S, Nimitha P, Kaul S, Valakkada J, Verma KK, Ramam M, et al. Primary cutaneous histoplasmosis in an immunocompetent patient presenting with severe pruritus. Indian J Dermatol Venereol Leprol. 2018;84(4):465-8. 